\title{
HIGH OUTCROSSING RATE AND POLLEN DISPERSAL DISTANCE of Diospyros celebica Bakh. (EBENACEAE), AN ENDEMIC TREE SPECIES IN SULAWESI ISLAND, INDONESIA
}

\author{
MUHAMMAD RESTU, GUSMIATY G. and SITI HALIMAH LAREKENG* \\ Biotechnology and Tree Breeding Laboratory, Faculty of Forestry, Universitas Hasanuddin, \\ Makassar 90245, Indonesia
}

Received 23 November 2015/Accepted 23 May 2017

\begin{abstract}
Diosphyros celebica Bakh., also known as Sulawesi ebony, is an endemic to central and northern Sulawesi. Information about pollen dispersal patterns of $D$. celebica have not been previously investigated. This study was aimed to determine pollination type, percentage of selfing and outcrossing, as well as distance of pollen dispersal of $D$. celebica. This study was conducted at experimental forest of Universitas Hasanuddin, Maros District, South Sulawesi Province, Indonesia. One hundred and sixty six individuals of D. celebica consisted of adult trees and seedlings were analyzed in this study. Ninety four adult trees were selected to become parent trees. The trees were mapped with GPS coordinates. All samples were genotyped using four SSR markers loci. Parental analysis and determination of pollen dispersal patterns were carried out using Cervus 3.0.3. Results indicated that the evaluated markers were effective for assigning candidate of male parents to all evaluated seedlings. Donated pollens could come from male parents in any directions relative to female parent positions. Pollen dispersal pattern showed outcrossing pollination among different male parents (pollen donated trees). The results indicated that seeds were produced predominatly by outcrossing. Pollen dispersal reached up to $166 \mathrm{~m}$. Pollen related processes were linked through female parents, pollinators availability and ecological environment. Simultaneous use of progeny genotyping, spatially explicit analysis of environmental variables and outcomes of plant-animal interactions were the key elements for an expanded approach to gene flow analysis considering dispersal via pollen and seeds. Research on pollen dispersal of D. celebica should be carried out in other forest types, such as mixed forest and highland forest.
\end{abstract}

Keywords: Diospyros celebica Bakh., endemic species, microsatellite marker, parentage analysis, pollen dispersal

\section{INTRODUCTION}

Recent endangered status of several ebony species in natural forests are within worldwide attention (World Conservation Monitoring Centre 1998). Diosphyros celebica Bakh. (Ebenacea), also known as Sulawesi ebony, is an endemic tree to Sulawesi Island, Indonesia.

This ebony species is currently categorized as vulnerable species according to the IUCN Red List of Threatened Species (e.T33203A9765120, World Conservation Monitoring Centre 1998). Previous study by Restu (2007) indicated that genetic diversity of $D$. celebica is low compared to other forest plants. The study found that all five of

\footnotetext{
* Corresponding author: sitih5h.82@gmail.com
}

D. celebica provenances studied showed higher homozygosity, due to probable self-pollinating or mating among related individuals. Therefore, their genetic diversity was lower (95.4\%) than those of other plants. Species with very narrow genetic base usually produce bad genetic planting stock material due to inbreeding depression. In order to prevent Sulawesi ebony from becoming endangered species, conservation strategy is needed.

Knowledge on pollen dispersal distance and mating system estimate are vital for developing effective conservation and management strategies of endangered species. These parameters may be directly translated into information about minimum density of individuals or minimum area required to avoid reproductive isolation (Nason $e t$ 
al. 1998). Pollen flow studies involving isolated individuals can assess the role of these individuals in pollen movement dynamics within fragmented landscapes. Trees increase the number of pollen donors by implementing long distance pollen dispersal and higher outcrossing rate, as was observed in the Cuajiniquil population (Fuchs \& Hamrick 2011). Therefore, conservation effort should be directed to preserve such individuals. Removal of these individuals may negatively impact genetic composition of the remnant populations (Fuchs \& Hamrick 2011).

Molecular markers are useful in pollen dispersal studies because these markers are capable of identifying parental genotype, genetic diversity and progenies. Molecular markers and parentage analysis can be used to estimate selfing and outcrossing rate (Milleron et al. 2012). Microsatellite markers were used to determine genetic diversity in endangered species Dipterocarpus littoralis (Dwiyanti et al. 2014), Nothofagus sp. (Sola et al. 2016) and Paeonia jishanensis (Xu et al. 2016). Pollen dispersal of various plant species was carried out using parentage analysis (Austerlitz et al. 2004). Pollen dispersal evaluations were done in Quercus garryana (Marsico et al. 2009), Pinus koraiensis (Feng et al. 2010), Tectona grandis (Prabha et al. 2011), Phoenix canariensis (Saro et al. 2014), Cocos nucifera (Larekeng et al. 2015b) and Erbytrophleum suaveolens (Duminil etal. 2016).

Currently, there were no information about mating system and pollen dispersal pattern of $D$. celebica. This study was aimed to determine pollination type, percentage of selfing and outcrossing as well as distance of pollen dispersal in D. celebica.

\section{MATERIALS AND METHODS}

\section{Study Species}

D. celebica (Ebenacea) is an endemic tree to Sulawesi Island, Indonesia. In southern Sulawesi, this tree species can be found in Gowa, Maros, Pangkep, Barru, Sidrap, Luwu and East Luwu districts. This tree can also be found in western Sulawesi (Mamuju) and central Sulawesi
(Donggala, Parigi Moutong and Poso). Protected forest is the main location for this species (Asdar et al. 2015).

Adult tree may reach up to $40 \mathrm{~m}$ high having 10 to $26 \mathrm{~m}$ clear bole. Trunk diameter is over $1.5 \mathrm{~m}$ above root crown. The root crown can reach $4 \mathrm{~m}$ high. The tree has simple, alternate, long elliptical leaves. Each leaf has length of 12 to $35 \mathrm{~cm}$, width of 2.5 to $7 \mathrm{~cm}$ and brown leaf hair (trichome) at the underside leaf surface which is a specific characteristic of D. celebica (Riswan 2002; Kinho 2013).

This species has monoecious flowers which means female and male gametes are found in a tree. Pollination occurred in the same tree resulted to either imperfect fruits or fruits that will be aborted before reaching maturation (Santoso et al. 2002a). Flowers are grown at the fourth axillary (flos axillary) from twig base or at the seventh axillary from twig tip. Flowers are commonly formed in the middle section of the canopy. Flowering is influenced by wind, rainfall, light and temperature (Santoso 2002b).

\section{Study Site}

D. celebica trees used for this study were located at the experimental forest of Universitas Hasanuddin. This experimental forest is a nonfragmented forest. The area is administratively located mostly in Limampocoe Village, Cenrana Subdistrict (previously known as Camba Subdistrict), Maros District, South Sulawesi Province, Indonesia (119 44'34" - 119 46'17" E and $04^{\circ} 58^{\prime} 7^{\prime \prime}$ - $\left.05^{\circ} 00^{\prime} 30^{\prime \prime} \mathrm{S}\right)$, with altitude of $300-800 \mathrm{~m}$ (Fig. 1). According to the Administration of Forestry, the area of experimental forest is part of Bulusaraung Forest, Bengo Police Forest, Lebbo Tengae Forest, Forest Service of Maros and Forest Service of South Sulawesi.

The study site consisted of plots and blocks. Each block was divided into several plots ranging from 50 to 170 ha (based on field conditions and tree types). Plots were bordered using natural boundaries, such as rivers and valleys. Plots within forest area were separated into subgroup plots based on tree type, age, tree density, vacant lot, natural forest and rocks. 


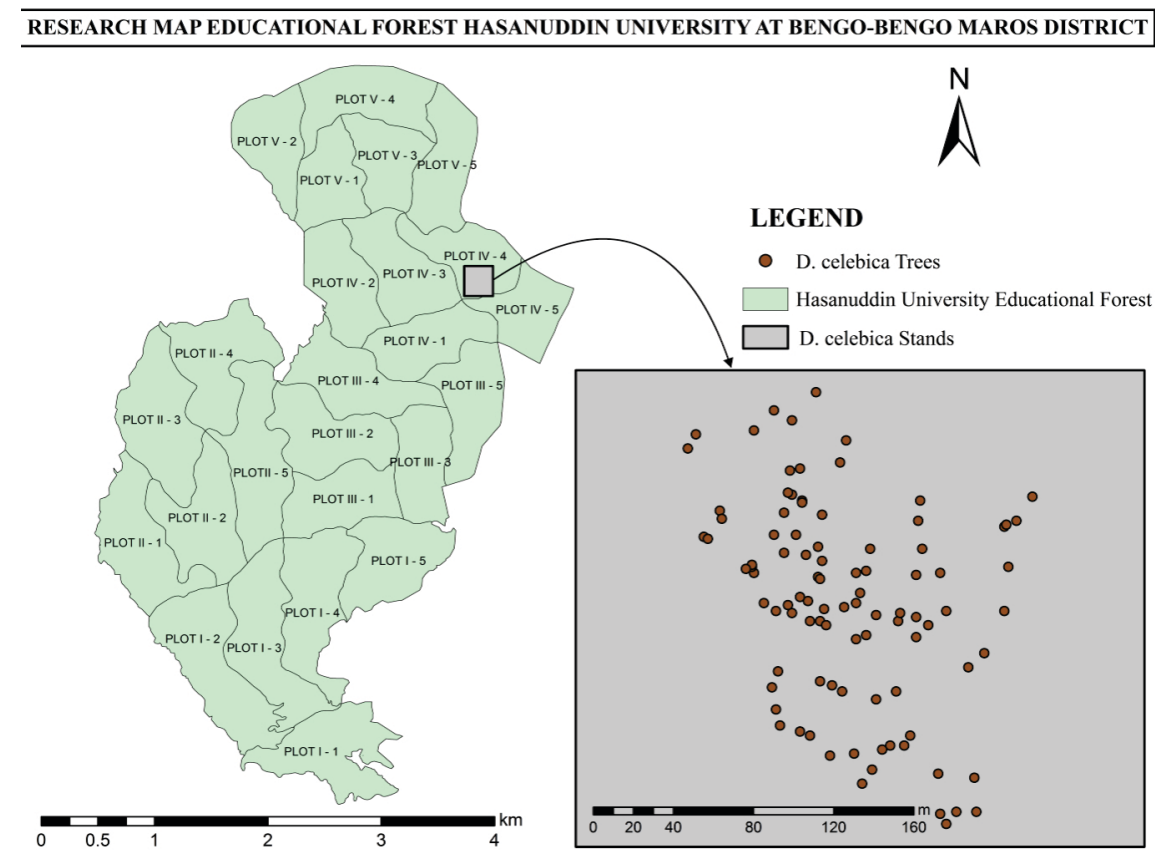

Figure 1. Map of study site: experimental forest of Universitas Hasanuddin

(Note: the $\bigcirc$ mark in this map indicates the positions of male and female parents of D. celebica)

\section{Sampling}

One hundred and sixty six individuals of $D$. celebica consisted of adult trees and seedlings were analyzed in this study. Ninety four adult trees were selected to become parent trees. Eleven of the 94 individuals were used as female and male parents. Female parent was a tree having seedlings grown under its canopy. The assumption was that seedlings grown right under the canopy of a tree was produced by the tree. Only 11 of 94 adult trees had seedlings. Two to ten seedlings from each evaluated female parent were selected. Thus, the total of evaluated seedlings was 72 seedlings. Leaves from adult trees and seedlings were used as DNA sources.

Sample collection was conducted in November 2015. In the study site, only 94 adult trees had seedlings grown under their canopies, which might be caused by early flowering time at the collection time. Alrasyid (2002) stated that flowering time of D. celebica was in March - April and fruit ripening time was in September November. The location of the female and the assigned male parents were plotted in the map of adult individuals generated by Arcgis 10.1 software.

\section{Microsatellite Analysis}

DNA isolation was conducted using the CTAB method (Sambrook \& Russell 2001) with modification (Larekeng 2015). RNA contaminants were removed using RNase treatment following standard procedures (Sambrook \& Russel 2001). Seventeen SSR markers loci generated by Liang et al. (2015) were evaluated to observe their polymorphism. Only four loci were selected for this study. To generate markers, PCR amplifications were conducted using the following reaction mixtures i.e. $2 \mu \mathrm{L}$ of DNA; $0.625 \mu \mathrm{L}$ of primers, $6.25 \mu \mathrm{L}$ PCR mix (KAPA Biosystem), and $3 \mu \mathrm{L} \mathrm{ddH}_{2} 0$. Amplifications were conducted using the following steps: one cycle of pre-amplification at $94{ }^{\circ} \mathrm{C}$ for 5 minutes, 35 cycles of amplification steps at $94{ }^{\circ} \mathrm{C}$ for 15 seconds (template denaturation), annealing temperature for 15 seconds (primer annealing) and $72{ }^{\circ} \mathrm{C}$ for 5 seconds (primer extension), and one cycle of final extension at $72{ }^{\circ} \mathrm{C}$ for 10 minutes as suggested by KAPA Biosystem kit.

The generated SSR markers were separated using Superfine Resolution Agarose 3\% (Seng et al. 2013) using TAE 0.5x buffer (Brody \& Kern 
2004) and stained using gel red staining. The electrophoregrams were visualized over UV transluminescence table and recorded by digital camera. The recorded pictures were used to determine genotypes of the evaluated samples. The laboratory activities were done at the Biotechnology and Tree Breeding Laboratory, Faculty of Forestry, Universitas Hasanuddin, Makassar, Indonesia.

\section{Parentage Analysis}

Each sample of the progeny arrays had a known female parent, but unknown male parent (as pollen donor). The candidates of male parent could come from any sampled adult population, including the female parent population. This study was conducted to determine the assigned male parent donating pollen to generate progeny arrays. Parentage analysis using genotype of progenies, female parents and potential male parents was done using CERVUS version 3.0.3 software (Kalinowski et al. 2007; Marshall et al. 1998). The progeny and female parent genotypes were compared with those of other adult trees. The assigned male parent was selected based on the output of CERVUS analysis results (Kalinowski et al. 2007; Marshall et al. 1998). Potential male parent with positive Likelihood of Odds score (LOD score) might be the actual male parent of the progeny (Marshall et al. 1998). The LOD score was determined based on the matching genotype of progeny, female parent and potential male parent.

Simulation was conducted to determine the threshold level for the 80 and 95\% confidence levels before the final parentage analysis step. Male parents assigned to each progeny were identified based on parentage analysis (Maskromo et al. 2016).

\section{Analysis of Pollen Dispersal Pattern}

Distance between the known female parent and the assigned male parent was calculated using ArcGis 10.1 software. Distance between and position of both female and male parents in the generated map were then used to illustrate pattern of pollen dispersal in the location. Selfpollination was defined as male parent being identical to female parent. Otherwise, they were assigned as cross-pollination.

\section{RESULTS AND DISCUSSION}

\section{Microsatellite Analysis}

PCR amplification was done by four SSR primers obtained from Diospyros kaki (Liang et al. 2015), modified based on research carried out by Larekeng et al. (2016). Nine of 17 SSR primers were able to produce polymorphic, strong and clear alleles on the DNA of Sulawesi ebony grown in the experimental forest of Universitas Hasanuddin, i.e. Maros provenance. Selected primer pairs are displayed in Table 1.

DNA amplification of SSR markers of Sulawesi ebony Maros provenance was an initial step of the use of specific primers for molecular genome research on Sulawesi ebony. SSR markers were intensively used in various molecular analyses, such as genetic diversity analysis between and among populations, genetic stability analysis in clonal plants derived from in vitro somatic embryogenesis, parents and progeny

Table 1 SSR loci used for pollen dispersal analysis of Sulawesi ebony from Maros provenance

\begin{tabular}{|c|c|c|c|c|}
\hline $\begin{array}{c}\text { Locus name/ } \\
\text { genbank accession no. }\end{array}$ & Repeat motif & Primer sequence $\left(5^{\prime}-3^{\prime}\right)$ & $\begin{array}{l}\mathrm{Tm} \\
\left({ }^{\circ} \mathrm{C}\right)\end{array}$ & $\begin{array}{l}\text { Allele size } \\
\text { (bp) }\end{array}$ \\
\hline $\begin{array}{l}1430 \\
\text { DC588341 }\end{array}$ & $(G A G) 5$ & $\begin{array}{l}\text { F: TCA GTA AAG CTG CGG GCA TC } \\
\text { R: ACG GTT CTC CTG ATC CTC ACG }\end{array}$ & 56 & $190-250$ \\
\hline $\begin{array}{l}8917 \\
\text { DC591591 }\end{array}$ & $(\mathrm{AT}) 10$ & $\begin{array}{l}\text { F: ACA CGT TCA GTA CCA GGA GGG A } \\
\text { R: AGT ACC ACA AAC C AC CAG TGG }\end{array}$ & 55 & $166-197$ \\
\hline $\begin{array}{l}9004 \\
\text { DC591297 }\end{array}$ & $($ GCAGGA) 3 & $\begin{array}{l}\text { F: GCC ACA AAC TTC ACA GAG GAC C } \\
\text { R: AGG CGA GTG CGA GTA AGA CGA A }\end{array}$ & 55 & $251-272$ \\
\hline $\begin{array}{l}\text { ssrDK29 } \\
\text { DQ097497 }\end{array}$ & (CСТT'T) 8 & $\begin{array}{l}\text { F: ATCATGAGATCAGAGCCGTC } \\
\text { R: CACGTTAACGTTACGGAACA }\end{array}$ & 53 & $112-152$ \\
\hline
\end{tabular}

Source: Liang et al. 2015 
arrays as well as pollen dispersal analysis (Larekeng et al. 2016). Primer screening was required to obtain strong and clear polymorphic-band pattern of PCR products. The intended PCR products were chosen from random primers. Not all tested nucleotide primer pairs produced amplified products (positive primer). Also, not all positive primer pairs produced good polymorphic DNA fragments (Siregar et al. 2008).

\section{Parentage Analysis}

Parentage analysis was able to identify the male parents for 72 progeny arrays. The results of parentage analysis also indicated that male parents assigned to the $25 \%$ of progenies (18 individuals) were at least in the minimum of $95 \%$ confidence level. Those assigned to the $51.4 \%$ of progenies (37 individuals) were at least in the minimum of $80 \%$ confidence level. Male parents assigned to the other $23.6 \%$ of progenies (17 individuals) were at lower-than- $80 \%$ confidence level. At the lower-than- $80 \%$ confidence level, however, the assigned male parents had positive LOD score, indicating that these male parents were the possible true parents of the progenies (Marshall et al. 1998).

Female parents of D. celebica could reciprocally donate their pollens and thus, performed selfpollination. Within the male parents assigned to the 72 progeny arrays, self-pollination occurred in 8 events $(11.1 \%)$ and cross pollination occurred in 64 events $(88.9 \%)$. Complete scheme and pollination types identified based on results of pollen dispersal analysis are presented in Table 2 .
Larekeng et al. (2015a) showed that pollination rate in Tall Kalianda Coconut was 98\% outcrossing, while the other $2 \%$ was selfpollination. Self-pollination provided higher reproductive assurance (RA) by compensating a shortage of outcross pollen. The role of selfpollination in mitigating pollen limitation in a selfcompatible population was rarely evaluated. The assay of limited pollen commonly used in selfpollination did not adequately quantify the potential fecundity advantage of RA (Eckert et al. 2010).

\section{Pattern of Pollen Dispersal}

In this study, parentage analysis was conducted using CERVUS. Distance between the known female parent and the assigned male parent was calculated using ArcGis 10.1 software. The results showed that range of pollen dispersal was $0-166$ (Table 2). The farthest pollen dispersal was exhibited by female parent number 35 (Table 2). Distance between female parents and the assigned male parents were determined based on their GPS positions (Fig. $2 \& 3$ ).

Female parent (PE 63) received 6 donated pollens from four different assigned male parents (PE 27, 34, 35, 71) (Fig. 2). Positions of the assigned male parents relative to the female parent (PE 63) in the study site are presented in Figure 2.

Female parent (PE 65) received 10 donated pollens from three different assigned male parents (PE 27, 45, 71) (Fig. 3). Positions of the assigned male parents relative to the female parent (PE 65) in the study site are presented in Figure 3.

Table 2 Crossing schemes and pollination types identified based on results of pollen dispersal analysis of $D$. celebica progeny arrays

\begin{tabular}{cccccl}
\hline No & $\begin{array}{c}\text { Female } \\
\text { parents }\end{array}$ & $\begin{array}{c}\text { Number of } \\
\text { seedling }\end{array}$ & $\begin{array}{c}\text { Selfing rate } \\
(\%)\end{array}$ & $\begin{array}{c}\text { Crossing rate } \\
(\%)\end{array}$ & \multicolumn{1}{c}{$\begin{array}{c}\text { Pollen dispersal distance } \\
\text { for each seedlings (m) }\end{array}$} \\
\hline 1 & 7 & 5 & 0 & 100 & $50 ; 52 ; 126 ; 50 ; 126$ \\
2 & 17 & 2 & 0 & 100 & $102 ; 152$ \\
3 & 22 & 6 & 0 & 100 & $51 ; 51 ; 51 ; 102 ; 102 ; 51$ \\
4 & 27 & 8 & 62.5 & 37.5 & $93 ; 0 ; 93 ; 0 ; 93 ; 0 ; 0 ; 0$ \\
5 & 35 & 3 & 66.7 & 33.3 & $0 ; 0 ; 166$ \\
6 & 50 & 8 & 0 & 100 & $60 ; 60 ; 64 ; 51 ; 44 ; 44 ; 51 ; 60$ \\
7 & 54 & 9 & 0 & 100 & $77 ; 77 ; 77 ; 77 ; 39 ; 21 ; 8 ; 71 ; 71$ \\
8 & 62 & 4 & 0 & 100 & $43 ; 43 ; 43 ; 107$ \\
9 & 63 & 10 & 0 & 100 & $43 ; 35 ; 66 ; 66 ; 53 ; 53 ; 66 ; 53 ; 52 ; 112$ \\
10 & 65 & 10 & 0 & 100 & $92 ; 39 ; 79 ; 79 ; 79 ; 79 ; 79 ; 92 ; 39 ; 92$ \\
11 & 67 & 7 & 28.6 & 71.4 & $0 ; 81 ; 82 ; 0 ; 134 ; 134 ; 81$ \\
\hline
\end{tabular}




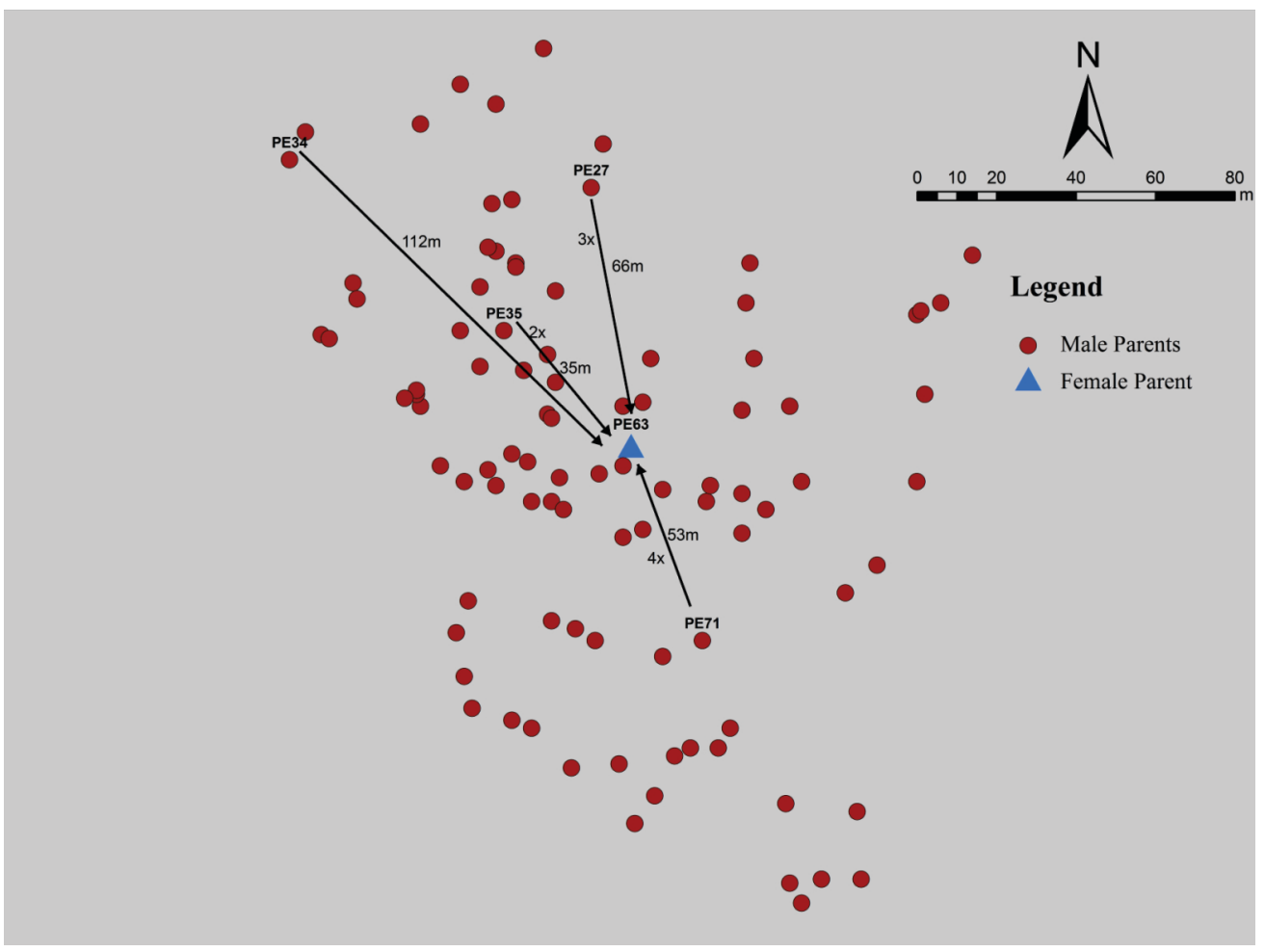

Figure 2 Pattern of pollen movement to female parent PE63 (A) based on parentage analysis (Note: the $\bigcirc$ mark in this map indicates the positions of D. celebica male parents)

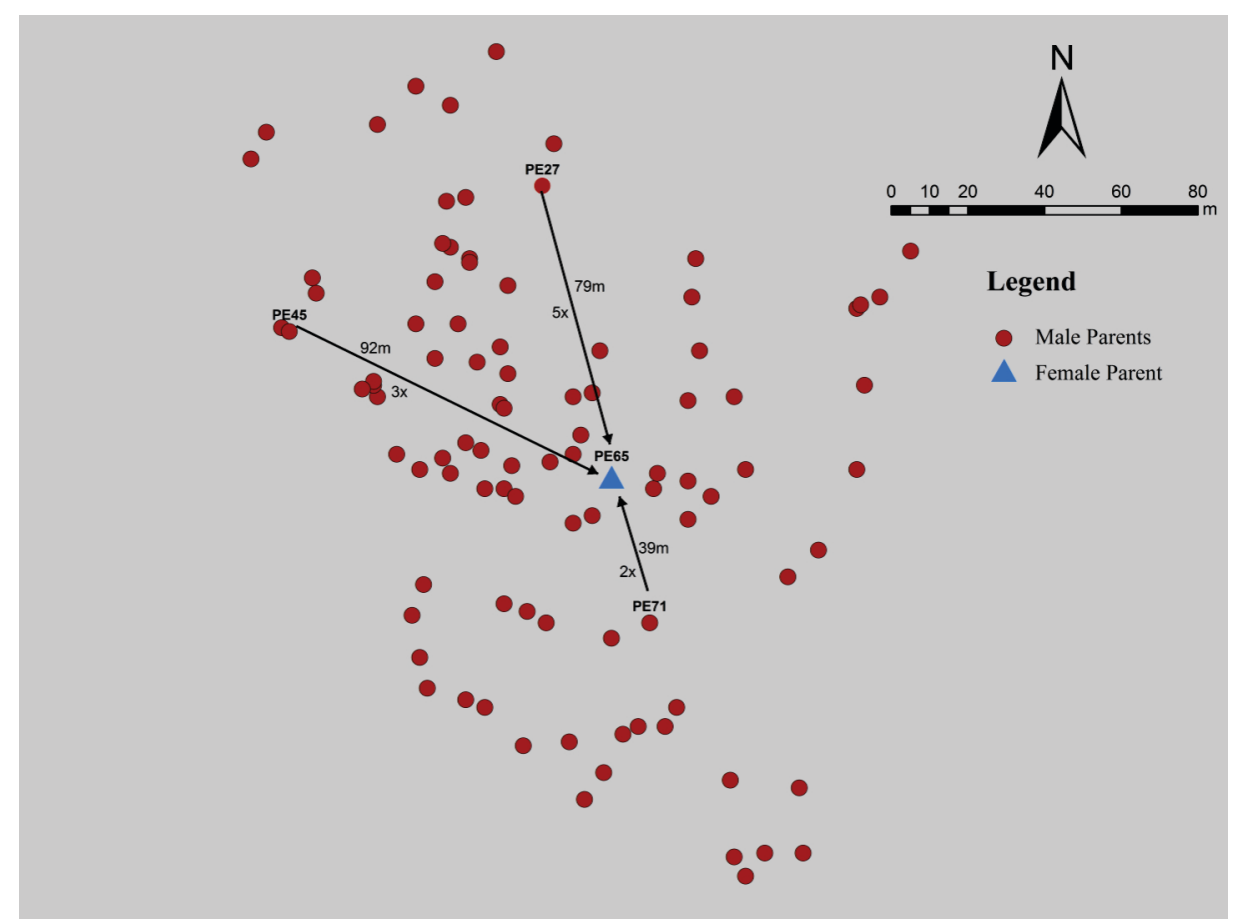

Figure 3 Pattern of pollen movement to female parent PE65 (A) based on parentage analysis (Note: the $\bigcirc$ mark in this map indicates the positions of D. celebica male parents) 


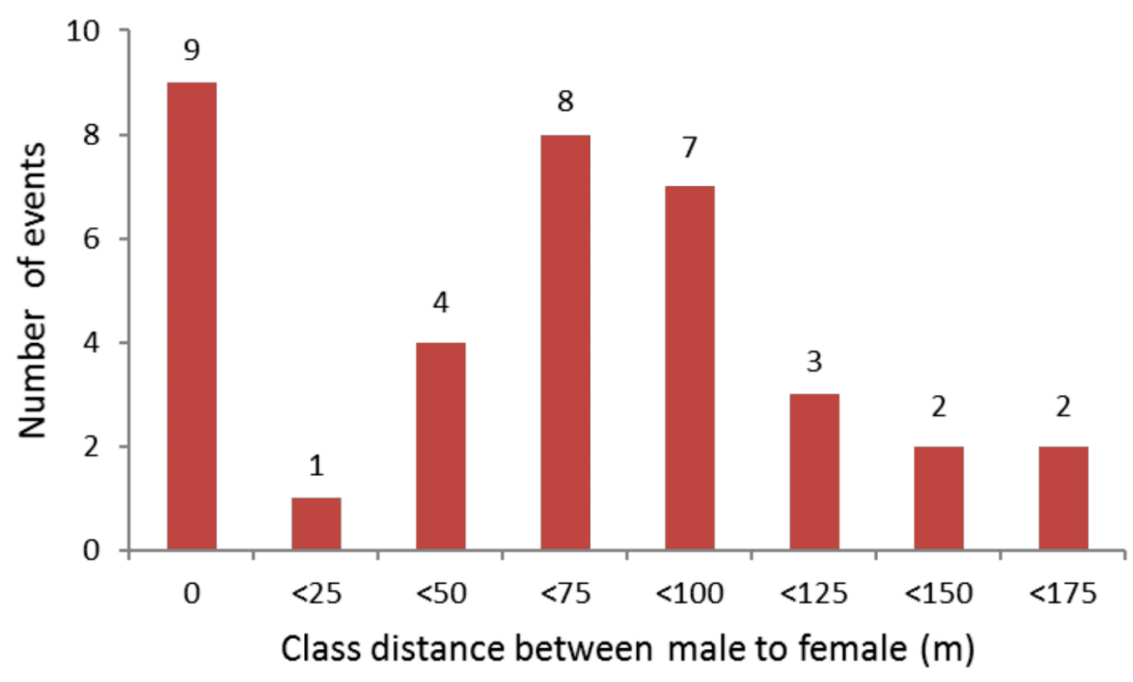

Figure 4 Numbers of pollination events for each distance class

Numbers of pollination events for each distance class are presented in Figure 4. The assigned male parents were distributed almost evenly among different distance classes of the female parents. The $0 \mathrm{~m}$ distance indicated selfpollination events.

A pollen dispersal study on Oenocarpus bataua, an insect-pollinated palm tree species, showed that pollen dispersal could be very far, exceeding the distance to the nearest neighbor (Ottewell et al. 2012).

Molecular microsatellite loci (SSRs) implemented in a study on mating system and pollen dispersal of Hymenaea coubarilindicated that several events of self-pollination occurred in this tree species (Carneiro et al. 2011), although it was previously believed that this tree species had obligatory crossing mating system due to a probable self-incompatibility system (Dunphy et al. 2004).

A study on Guaiacum sanctum (an endangered tree species) showed the predominant outcrossing characteristic of this tree species (Fuchs \& Hamrick 2011). The study also showed that the supra-annual flowering in Palo Verde National Park (PVNP) might reduce the numbers of reproducing individuals, affecting the proportion of outcross progeny. The study further discussed that population of $G$. sanctum should preserve enough adults to ensure seed production even in a period when only few individuals reproduce. The same study suggested that in a fragmented population, pollen dispersal can be very far and thus, pollen is readily transported across the fragmented population or altered habitats to ensure tree species preservation.

Further investigations on genetic diversity of D. littoralis should concentrate on life history characteristics, mechanisms of pollen/seed dispersal, seed germination, vegetative propagation and impacts from herbivores and pathogens (Dwiyanti et al. 2014). Simultaneous use of progeny genotyping, spatially explicit analysis of environmental variables and the outcomes of plant-animal interactions are key elements for an expanded approach to gene flow analysis considering dispersal via pollen and seeds.

D. celebica is an endangered tropical tree species and currently, only few information is available concerning reproductive biology of this tree species. Conservation genetics theory suggested that significant size of population should be preserved to ensure the maintenance of genetic diversity and to reduce detrimental effects of drift and inbreeding. Mating system and gene-flow distance estimates allow better predictions of minimum viable population sizes, ensuring reproductive success.

\section{CONCLUSIONS}

Pollen dispersal pattern of Sulawesi ebony occurred in outcrossing pollination among its different donated trees. Based on the progenies analysis, ebony female parent is a dominantly outcrossing pollination species. The results 
parentage analysis from Diosphyros celebica Bakh. In Sulawesi island shows range of pollen dispersal was $0-166 \mathrm{~m}$.

\section{ACKNOWLEDGEMENTS}

The authors thank Yuni Fitri Cahyaningsih and Mirza Arsiaty Arsyad for their assistance in the laboratory works and manuscript writing.

\section{REFERENCES}

Alrasyid H. 2002. Kajian budidaya pohon Eboni. Berita Biologi [edisi khusus: Manajemen Eboni] 6(2):21925.

Asdar M, Prayitno TA, Lukmandaru G, Faridah E. 2015. Sebaran, potensi dan kualitas kayu Eboni (Diospyros celabica Bakh.) di Sulawesi.J Agroland 22 (2):94-105.

Austerlitz F, Dick CW, Klein EK, Muratorio SO, Smouse PE, Sork VL. 2004. Using a genetic markers to estimate the pollen dispersal curve. Mol Ecol 13:93754.

Brody JR, Kern SE. 2004. History and principles of conductive media for standard DNA electrophoresis. Anal Biochem 333(1):1-13.

Carneiro FS, Lacerda AEB, Lemes MR, Gribel R, Kanashiro M, Wadt LHO, Sebbenn AM. 2011. Effects of selective logging on the mating system and pollen dispersal of Hymenaea courbaril L. (Leguminosae) in the Eastern Brazilian Amazon as revealed by microsatellite analysis. For Eco 262:1758-65.

Duminil J, Daïnou K, Kaviriri DK, Gillet P, Loo J, Doucet JL, Hardy OJ. 2016. Relationships between population density, fine-scale genetic structure, mating system and pollen dispersal in a timber tree from African rainforests. Heredity 116(3):295-303. DOI: 10.1038/hdy.2015.101.

Dunphy BK, Hamrick JL, Schwagerl J. 2004. A comparison of direct and indirect measures of gene flow in the bat-pollinated tree Hymenaea courbarilin the dry forest life zone of south-western Puerto Rico. Int J Plant Sci 165:427-36.

Dwiyanti FG, Harada K, Siregar IZ, Kamiya K. 2014. Population genetics of the critically endangered speices Dipterocarpus littoralis Blume (Dipterocarpaceae) endemic in Nusakambangan Island, Indonesia. BIOTROPIA 21(1):1-12. DOI:10.11598/btb.2014.21.1.1.

Eckert CG, Kalisz S, Geber MA, Sargent R, Elle E, Cheptou PO, ... Winn AA. 2010. Plant mating systems in a changing world. Trends Ecol Evol 25:35-43. DOI: 10.1016/j.tree.2009.06.013.
Feng FJ, Sui X, Chen MM, Zhao D, Han SJ, Li MH. 2010. Mode pollen spread in clonal seed orchard of Pinus koraiensis. Biophys Chem 1(1):33-39.

Fuchs EJ, Hamrick JL. 2011. Mating system and pollen flow between remnant populations of the endangered tropical tree, Guaiacum sanctum (Zygophyllaceae). Conserv Genet 12:175-85. DOI: 10.1007/s10592010-0130-8.

Kalinowski ST, Taper ML, Marshall TC. 2007. Revising how the computer program Cervus accommodates genotyping error increases success in paternity assignment. Mol Ecol 16:1099-106.

Kinho J. 2013. Mengembalikan kejayaan Eboni di Sulawesi Utara. Kementerian Kehutanan, Badan Penelitian dan Pengembangan Kehutanan, Balai Penelitian Kehutanan. Manado (ID): Buletin Litbang. p. 18-20.

Larekeng SH. 2015. Pollen dispersal analysis of Kopyor Coconut (Cocos nucifera L.) in Pati and Kalianda using SSR and SNAP markers for supporting plant breeding. [Thesis]. Bogor (ID): Institut Pertanian Bogor.

Larekeng SH, Maskromo I, Purwito A, Mattjik NA, Sudarsono S. 2015a. Penyebaran polen berdasarkan analisis SSR membuktikan penyerbukan Kelapa Dalam Kalianda Normal ke Kopyor. Buletin Palma 16(1):77-92.

Larekeng SH, Maskromo I, Purwito A, Mattjik NA, Sudarsono S. 2015b. Pollen dispersal and pollination patterns studies in Pati Kopyor Coconut using molecular markers. CORD 31(1):46-60.

Larekeng SH, Restu M, Gusmiaty, Rismawati. 2016. Polymorphism of simple sequence repeat regions of Sulawesi Ebony (Diosphyros celebica Bakh.) in experimental forest of Hasanuddin University Provenance. Agrotech Journal 1(1):38-44. Available from: http://usnsj.com/index.php/ATJ/article/ view/ATJ007.

Liang Y, Weijuan H, Peng S, Jinjun L, Tana W, Fangdong L, Jianmin F. 2015. Genetic diversity among germplasms of Diospyros kaki based on SSR markers. Sci Horti 186:180-9.

Maskromo I, Larekeng SH, Hengky N, Sudarsono S. 2016. Xenia negatively affecting kopyor nut yield in Kalianda Tall kopyor and Pati Dwarf kopyor coconuts. Emir J Food Agric 28(9):644-52. DOI: 10.9755/ejfa.2015-07-552.

Marshal TC, Slate J, Krilek LEB, Pemberton JM. 1998. Statistical confidence for likehood based paternity inference in nature populations. Mol Ecol 7:639-55.

Marsico TD, Jessica JH, Romero-Saverson J. 2009. Patterns of seed dispersal and pollen flow Quercus garryana (Fagaceae) following post-glacial climatic changes. J Biogeogr 36(5):929-41. 
Milleron M, de Heredia UL, Lorenzo Z, Perea R, Dounavi A, Alonso J, ... Nanos N. 2012. Effect of canopy closure on pollen dispersal in a wind-pollinated species (Fagus sylvatica L.). Plant Ecol 213:1715-28.

Nason JD, Herre EA, Hamrick JL. 1998. The breeding structure of a tropical keystone plant resource. Nature 391:685-7.

Ottewell K, Grey E, Castillo F, Karubian J. 2012. The pollen dispersal kernel and mating system of an insectpollinated tropical palm, Oenocarpus batana. Heredity 109:332-9.

Prabha SS, Indira EP, Nair PN. 2011. Contemporary gene flow and matting system analysis in natural teak forest using microsatellite markers. Curr Sci 101(9): 1213-9.

Restu M. 2007. Genetic variability of five provenances of Ebony (Diospyros celebica Bakh). Jurnal Natur Indonesia 10(1):7-12. ISSN:1410-9379.

Riswan S. 2002. Kajian bologi Eboni (Diospyros celebica Bakh). Berita Biologi [edisi khusus: Manajemen Eboni] 6(2):211-8.

Sambrook J, Russel DW. 2001. Molecular cloning: a laboratory manual. Third edition. New York (US): Cold Spring Harbor Laboratory Press.

Santoso B, Anwar C, Nompo S. 2002a. Pembudidayaan pohon Eboni (Diospyros celebica Bakh.). Berita Biologi [edisi khusus: Manajemen Eboni] 6(2):277-82.
Santoso, B. 2002b. Status dan strategi pemuliaan pohon Eboni (Diospyros celebica Bakh.). Berita Biologi [edisi khusus: Manajemen Eboni] 6(2):315-9.

Saro I, Robledo-Arnuncio JJ, González-Pérez MA, Sosa PA. 2014. Patterns of pollen dispersal in a small population of the Canarian endemic palm (Phoenix canariensis). Heredity 113(3):215-23. DOI: 10.1038/hdy.2014.16.

Seng TY, Singh R, Faridah QZ, Tan SG, Alwee SSRS. 2013. Recycling of superfine resolution agarose gel. Genet Mol Res 12(3):2360-7.

Siregar IZ, Yunanto T, Pamoengkas P. 2008. Implikasi genetik metode pembiakan tanaman Shorea johorensis Faxw pada sistem silvikultur Tebang Pilih Tanam Jalur (TPTJ). Biodiversitas 9(4):250-4. DOI: 10.11057/biodiv/d090402.

Sola G, El V, Tsuda Y, Giuseppe G, Gallo L. 2016. Forest ecology and management the effect of silvicultural management on the genetic diversity of a mixed Nothofagus forest in Lanín Natural Reserve, Argentina. For Ecol Manage 363:11-20. DOI: 10.1016/j.foreco.2015.12.018.

World Conservation Monitoring Centre. 1998. Diospyros celebica. The IUCN Red List of Threatened Species 1998: e.T33203A9765120.

Xu X, Cheng F, Xian H, Peng L. 2016. Genetic diversity and population structure of endangered endemic Paeonia jishanensis in China and conservation implications. Biochem Syst Ecol 66: 319-25. DOI: 10.1016/j.bse.2016.05.003. 